\title{
Terrestrial Insects as the Main Food for Freshwater Fish in Sungai Kerian Tributaries: An Implication on Habitat Conservation
}

(Serangga Darat sebagai Makanan Utama untuk Ikan Air Tawar di Anak Sungai Kerian: Implikasi ke atas Pemuliharaan Habitat)

\author{
MOHD ShaFiQ ZaKeyUdDiN*, MANSOR MAT Isa, CHE SALMAH Md RAWI, \\ AMIR SHAH RUDDIN MD SAH \& ABU HASSAN AHMAD
}

\begin{abstract}
The importance of terrestrial insects as food items for freshwater fish was studied by examining stomach contents of Devario regina (Fowler 1934) and its population parameters at canopied areas of selected tributaries of Sungai Kerian, in the northern state of Peninsular Malaysia. Ninety six percent (121 out of 126) of the fish stomachs examined contained food materials in the stomachs and the values of percentage of occurrence $(\% \mathrm{~F})$, percentage numerical (\%N) and percentage points $(\% P)$ indicated that collected fish ate similar food items in all rivers. Among the food categories, scavenging terrestrial ants (Formicidae) were the most dominant food item, hence the main diet for this species. The Index of Relative Importance (IRI) scores of food items indicated that ants were higher than other food items. This surface water feeder experienced a positive allometric growth $\left(W=a L^{b}\right)$ with a b (rate of growth) value of 3.256 . Its asymptotic length, growth constant and growth performance index represented this species with a short life-span $(L \infty=$ $10.90 \mathrm{~cm}, K=1.20$ year $^{-1}, \phi^{\prime}=2.15, t_{\max }=3$ year, respectively) and had higher natural mortality $\left(M=2.40\right.$ year $\left.{ }^{-1}\right)$ than fishing mortality $\left(F=0.35\right.$ year $\left.{ }^{-1}\right)$ while the fish stock was underexploited $(E=0.13)$. The finding of this study indicated the importance of terrestrial ants as a food source that support excellent growth of $\mathrm{D}$. regina and the need to conserve riparian trees along river banks to provide allocthonous materials and habitats for the ants.
\end{abstract}

Keywords: Devario regina; growth parameters; stomach content; Sungai Kerian

\section{ABSTRAK}

Kepentingan serangga darat sebagai bahan makanan bagi ikan air tawar telah dikaji dengan menentukan kandungan perut ikan Devario regina (Fowler 1934) dan parameter populasi di kawasan berkanopi di anak-anak sungai terpilih Sungai Kerian, di utara Semenanjung Malaysia. Sembilan puluh enam peratus (121 daripada 126) jumlah perut ikan yang dikaji mengandungi bahan makanan di dalam perut dan nilai peratus kekerapan (\% F), peratus bilangan (\%N) dan peratus markah (\%P) menandakan bahawa ikan tersebut makan makanan yang sama di semua sungai yang terpilih. Dalam kategori makanan, pengumpul makanan semut darat (Formicidae) adalah bahan makanan yang dominan, justeru merupakan diet utama bagi spesies ini. Tumbuh-tumbuhan menyumbang 6.49 kepada 10.92\% IRI untuk menjelaskan bahawa D. regina dikategorikan sebagai ikan omnivor. Ikan yang makan di permukaan air ini mengalami pertumbuhan alometrik positif $\left(W=a L^{b}\right)$ dengan nilai b (kadar pertumbuhan) iaitu 3.256. Panjang infiniti, pertumbuhan malar dan indeks prestasi pertumbuhan ikan ini menandakan ia mempunyai jangka hayat yang pendek $(L \infty=10.90 \mathrm{~cm}, \mathrm{~K}=1.20$ tahun $^{-1}, \phi^{\prime}=2.15, t_{\max }=3$ tahun $)$ dan kadar kematian semula jadi yang tinggi $\left(M=2.40\right.$ tahun $\left.^{-1}\right)$ berbanding kematian tangkapan $\left(F=0.35\right.$ tahun $\left.^{-1}\right)$ manakala stok ikan ini masih belum dieksploitasi $(E=0.13)$. Penemuan kajian ini menunjukkan kepentingan semut di darat sebagai sumber makanan yang membantu pertumbuhan cemerlang D. regina dan keperluan untuk memelihara pokok-pokok riparian sepanjang tebing-tebing sungai untuk membekalkan bahan-bahan alloktonus dan tempat tinggal bagi semut.

Kata kunci: Devario regina; kandungan perut; parameter pertumbuhan; Sungai Kerian

\section{INTRODUCTION}

Devario regina is a beautiful and popular ornamental fish species which commonly found in upland streams and in riverine ecosystems with sandy, gravel and cobble substrates (Rainboth 1996). The fish, recognized by several alternating dark and light stripe along the side (Fang \& Kullander 2009) usually moves in group (McClure et al. 2006; Rainboth 1996). In Peninsular Malaysia, D. regina was found in high abundance in Gunung Jerai (Shah et al. 2009) and Hulu Perak (Zakaria-Ismail \& Lim 1995). However the diet of this fish species has never been investigated. In other countries such as India and Thailand, the food habit of this fish species and other Devario fish, had been thoroughly studied (McClure et al. 2006). Feeding habit and food preference of ornamental fish is important for maintenance of the species in captivity as well as in 
its natural habitat or for conservation of the species in specific areas.

Biological performance of fish species has been commonly investigated using the length-weight relationship (LWR) (Abdurahiman et al. 2004; Ayoade \& Ikulala 2007; Frota et al. 2004; Golam \& Tawfeequa 2006; Jamabo et al. 2009; Odat 2003; Offem et al. 2009; Samat et al. 2008; Thomas et al. 2003). The information generated is important for evaluation of the general health parameters of fish species (fatness, breeding and feeding states) and their suitability to the environment (Farzana \& Saira 2008; González-Gándara et al. 2003; Schneider et al. 2000) as well as providing clues to the environmental changes and management of the stock (Efitre et al. 2009; Samat et al. 2008). For instance, Abowei (2009) analyzes the LWR of a commercial flat fish, Cynoglossus senegalensis in Nigeria and he finds that the $b$ value from the growth equation $\left(\mathrm{W}=\mathrm{a} \mathrm{L}^{\mathrm{b}}\right)$ indicates the rate of weight gain (Frota et al. 2004) closely follows the growth in length of the fish.

High availability of food resources is one of the main factors that determine the suitability of riverine habitats for fish growth which is reflected by the value of Relative Condition Factor $(K n)$. Higher $K n$ value reflects better habitat suitability for the optimum fish growth in relation to food availability and other requirements (Samat et al. 2008). However, the $K n$ value decreases during gonadal maturation and reproductive period ( $\mathrm{K}$ less than one) because the fish loses its weight after spawning (Froese 2006).

In addition to food resources, Sachidanandamurthy and Yajurvedi (2008) have shown that deterioration in water quality directly or indirectly affects fish physiology and growth. High water $\mathrm{pH}$ causes alkalosis, damaging skin, browning of gills areas and increasing mucus production. High ammonia increases the toxicity of water, causing ammonia poisoning to the fish, with symptoms such as red streaking on the body and gills may appear pale in colour. These types of diseases reduce or inhibit fish growth, affecting the value of growth coefficient $(b)$. Apart from fish distribution, very little is known about the ecology and exploitation levels of fishes in Sungai Kerian basin. Availability of food sources, food preferences as well as fish population parameters' estimation, including length-weight relationship, growth and mortality generated from the length-frequency data are ways to estimate wellbeing of fish species in their environment (Kolaneci et al. 2010). Therefore in this study, analysis of stomach content and population parameters of $D$. regina were studied to determine the suitability and wellness of Sungai Kerian tributaries as habitat for the fish.

\section{MATERIALS AND METHODS}

Sungai Kerian Basin $\left(5^{\circ} 9^{\prime}-5^{\circ} 21^{\prime} \mathrm{N}\right.$ and $100^{\circ} 36.5^{\prime}-$ $100^{\circ} 46.8^{\prime} \mathrm{E}$ ) is located in the northern part of Peninsular Malaysia and has a population of about 190,000 in a catchments area of $1418 \mathrm{~km}^{2}$ (Yap 1990). Sungai Kerian Basin is a formation of Sungai Kerian together with a number of tributaries that supply water to thousands of people downstream (Che Salmah et al. 2004). Sungai Kerian originates from the hilly headwaters in Sungai Mahang, Kedah while the Sungai Selama begins from hilly areas in Selama, Perak (Che Salmah et al. 2001). Sungai Mahang and Sungai Selama meet to form Sungai Kerian at the middle of the basin which eventually flows westward to the Strait of Malacca (Figure 1).

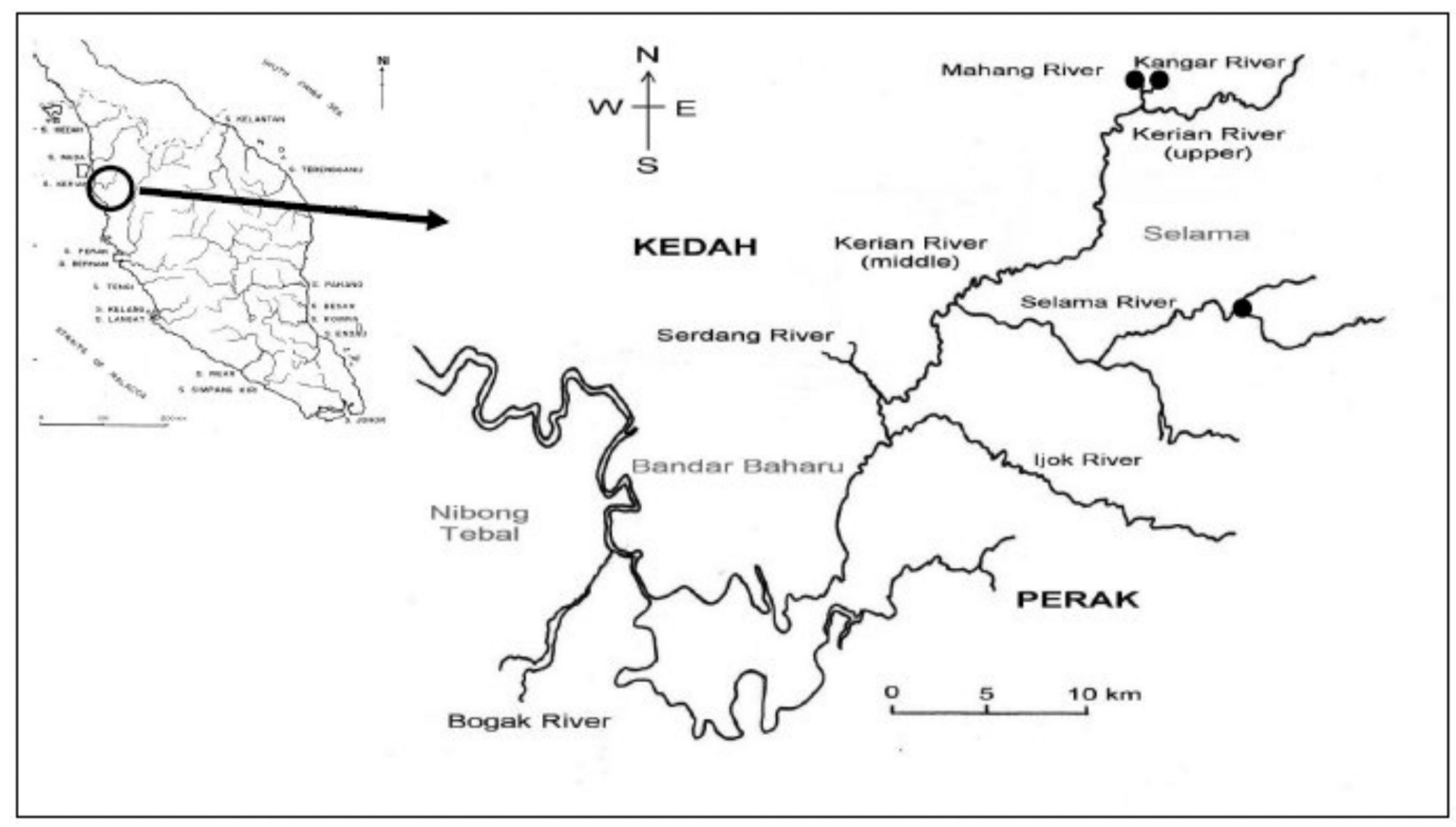

FIGURE 1. Location of sampling sites $(\bullet)$ along Sungai Kerian Basin in the northern of Peninsular Malaysia 


\section{DETERMINATION OFRIVER PHYSICO-CHEMICALPARAMETERS}

In this study, the following parameters were measured to describe the condition of Sungai Kerian tributaries. In situ physico-chemical readings were taken at each sampling site. Dissolved Oxygen (DO) content and temperature $\left({ }^{\circ} \mathrm{C}\right)$ were estimated using YSI meter (Model 55), conductivity $(\mu \mathrm{S} / \mathrm{cm})$, total dissolved solids (TDS) $(\mathrm{mg} / \mathrm{L})$ and salinity (ppt) were measured using Hach meter (Model CO150), $\mathrm{pH}$ was measured using Hach Sension 1 meter, velocity and depth of a river were estimated using velocity meter and width of a river was measured using a measuring tape. A Kruskal-Wallis Test was carried out to determine the differences for every parameter among the rivers.

The specimens of $D$. regina (Danio) were collected in selected Sungai Kerian tributaries from May 2008 to June 2009 using a cast net, an eloctrofishing and a scoop net. A total of $127 \mathrm{D}$. regina were collected during the study. D. regina was found in Sungai Mahang, upstream of Sungai Selama, Sungai Kangar and Sungai Serdang (Figure 1). However, only one specimen of D. regina was collected in Sungai Serdang which was excluded from this analysis. Details for each collecting site are given in Table 1. All specimens were transported to the laboratory in a Coolman ${ }^{\circledR}$ ice chest. The fish were identified to the lowest taxon possible using standard taxonomic keys of Ambak et al. (2010), Kottelat et al. (1993), Mohsin and Ambak (1983) and Rainboth (1996) and preserved in $10 \%$ formalin. The weight (in gram) of each specimen was measured using an electronic scale (Electronic Balance Model 6002). The total length was measured from the tip of the head to the tip of the caudal fin rays while standard length started from anterior mouthpart to the end of caudal peduncle.

\section{STOMACH CONTENT PREPARATION}

A total of $126 \mathrm{D}$. regina were used in the stomach content analysis by using methods as suggested by Hanjavanit and Sangpradub (2009) and Yamagishi et al. (2005). The stomach from each fish was dissected, weighed $(\mathrm{g})$ together with its content and preserved in 5\% formalin. The stomach contents were poured into a Petri dish before all preys were identified under the stereoscopic microscope. Insect preys were identified using Merritt and Cummins (1996), Merritt et al. (2008) and Yule and Yong (2004).

\section{STOMACH CONTENT ANALYSIS}

The diet of $D$. regina was described by recording their occurrence, numerical scores of each prey category and ranking the prey based on the combination of numerical, occurrence and abundance. The preys were recorded as percentage of the total quantity found in the stomach as suggested by Assis (1996).

\section{FREQUENCY OF OCCURRENCE METHOD}

Frequency of occurrence records the number of fish in which each food item occurs and expressed as a percentage of the total number of fish examined (Hynes 1950; Yap 1988). This method requires minimum equipment and very fast but it gives little indication of the relative amount of each food category present in the stomach (Adeyemi et al. 2009; Hyslop 1980). This method is calculated as:

$$
\text { Frequency of occurrence: [\%] } F_{i}=M_{i} / M_{\Sigma} \times 100 \text {, }
$$

where $M_{i}$ is the number of stomachs containing prey component $i$; and $M_{\Sigma}$ is the number of all food occurrence.

\section{NUMERICAL METHOD}

The number of individuals in each food category was recorded for all stomachs dissected and the total is expressed as a percentage of the total individuals in all food categories (Hynes 1950; Hyslop 1980). This method was fast and simple to operate but it overemphasizes the important of small prey items taken in large numbers (Hynes 1950; Hyslop 1980). The food items were not identified to the species level because most of them were crushed and almost completely digested. This method is calculated as:

TABLE 1. Descriptions of sampling sites from which Devario regina were collected

\begin{tabular}{|c|c|c|}
\hline Name of site & $\begin{array}{c}\text { Approximate sampling } \\
\text { location }\end{array}$ & Description of site \\
\hline Sungai Mahang & $\begin{array}{c}5^{\circ} 20^{\prime} 43.70 ” \mathrm{~N} \\
100^{\circ} 46^{\prime} 17.70^{\prime \prime} \mathrm{E}\end{array}$ & $\begin{array}{l}\text { A small hillstream river with steep river banks. It has relatively fast flowing } \\
\text { water, partially shaded by fruit trees and bamboo (Bambusa sp.), sand mining } \\
\text { areas and fruit orchards (Durio zibethinus, Nephelium lappaceum) on both } \\
\text { river banks. The main substrates for this river are sand and gravel }\end{array}$ \\
\hline Sungai Kangar & $\begin{array}{c}5^{\circ} 20^{\prime} 17.17^{\prime \prime} \mathrm{N} \\
100^{\circ} 46^{\prime} 28.30^{\prime \prime} \mathrm{E}\end{array}$ & $\begin{array}{l}\text { A small hillstream river with low gradient river banks. Its shallow, fast flowing } \\
\text { water is partially shaded by the riparian vegetation. The main substrate for } \\
\text { this river is sand }\end{array}$ \\
\hline Sungai Selama & $\begin{array}{c}5^{\circ} 15^{\prime} 34.60 ” \mathrm{~N} \\
100^{\circ} 500^{\prime} 42.10^{\prime \prime} \mathrm{E}\end{array}$ & $\begin{array}{l}\text { A moderate size hillstream river with low gradient river banks. It is located in } \\
\text { hilly areas with fruit orchards nearby. This river is relatively fast flowing with } \\
\text { the main substrates are boulder and cobble. This river is partially shaded by } \\
\text { riparian vegetations such as Koompassia malaccensis, Aglaonema nitidum, } \\
\text { Chassalia chartacea and Bambusa sp. }\end{array}$ \\
\hline
\end{tabular}


Numerical percentage of prey $i$ : [\%] $N=N_{i} / N_{\Sigma} \times 100$, where $N_{i}$ is the number of prey specimen of prey group $i$; and $N_{\Sigma}$ is the total number of prey detected.

\section{POINT METHOD}

A method in which the food items in each fish stomach were listed as common, frequent and rare based on the rough counts and visual judgement by eye. Each food item was allotted $1,2,4,8$ or 16 based on the size of the organisms as well as of their abundance (one large organism counted as much as a large number of small ones) (Hynes 1950). All points gained were summed to give percentage composition of the food of all fish examined (Hynes 1950; Lima-Junior \& Goitein 2001; Swynnerton \& Worthington 1940).

\section{INDEX OF RELATIVE IMPORTANCE (IRI)}

This method was the combination of three methods mentioned earlier to represent the most important diet in the stomach of D. regina. This method was calculated as IRI $=(\% \mathrm{~N}+\% \mathrm{P}) \times \% \mathrm{~F}$ where $\% \mathrm{~N}$ is a numerical percentage; $\% \mathrm{P}$ is a percentage of points; and $\% \mathrm{~F}$ is a percentage of occurrence (George et al. 2009; Hyslop 1980).

\section{LENGTH-WEIGHT RELATIONSHIP (LWR)}

The length-weight relationship (LWR) was estimated using the following formula $\mathrm{W}=a \mathrm{~L}^{b}$ (Le Cren 1951; Pauly 1983) where $\mathrm{W}$ is the weight of fish $(\mathrm{g})$; $\mathrm{L}$ is the total length of fish $(\mathrm{cm}) ; a$ is constant and $b$ is slope of regression line. The values of $a$ and $b$ were estimated through a logarithmic transformation; $\log \mathrm{W}=\log \mathrm{a}+$ blog $\mathrm{TL}$, the least square linear regression (Froese 2006). Value of $b$ is an index of growth type of fish (isometric or allometric) and useful for fish classification (Smith 1996), indicating isometric growth when the fish has an equal increment of both length and weight parameters $(b=3)$, the light group or negative allometric growth $(b<3)$, heavy group or positive allometric growth with $b>3$ (Ayoade \& Ikulala 2007; Jamabo et al. 2009; Laghari et al. 2009; Odat 2003; Offem et al. 2009; Samat et al. 2008; Smith 1996; Thomas et al. 2003). The length-weight relationship was subjected to regression analysis.

\section{RELATIVE CONDITION FACTOR $(K n)$}

The formula for relative condition factor is $K n=\mathrm{W} / \mathrm{W}$ ' (Le Cren 1951) where $W$ is the observed weight of individual fish $(\mathrm{g})$; and $W^{\prime}$ is the expected weight of fish $(\mathrm{g})$, which can be determined using the following formula $\mathrm{W}^{\prime}=a \mathrm{~L}^{b}$ (Le Cren 1951). The values of $K n$ are used to compare the well-being, healthiness of fish between species, between rivers or different sampling sites in the Sungai Kerian Basin. The result of $K n$ values for this species was analyzed using Kruskal-Wallis test at $p=0.05$ for non-normally distributed data.

\section{LENGTH-FREQUENCY DATA}

Analysis of length-frequency data was carried out using FISAT II software (Gayanilo et al. 2005) to estimate growth and mortality parameters. ELEFAN 1 (incorporated in FISAT) was used to sequentially arrange and restructure the monthly length-frequency data set (Uneke et al. 2010) to obtain asymptotic length $(\mathrm{L} \infty)$ and curvature parameter (K) (Kleiber \& Pauly 1991). The growth in length was described by the von Bertalanffy Growth Formula (vBGF) using the formula $\mathrm{L}_{\mathrm{t}}=\mathrm{L} \infty \times\left(1-\mathrm{e}^{-\mathrm{K}(\mathrm{t}-\mathrm{to})}\right)$ where $\mathrm{L}_{\mathrm{t}}$ is the mean total length (in $\mathrm{cm}$ ) of the fish at age $\mathrm{t}$; $\mathrm{L} \infty$ is the mean asymptotic length $(\mathrm{cm}) ; \mathrm{K}$ is a growth constant $\left(\right.$ year $\left.^{-1}\right)$; $\mathrm{t}$ is the age of the fish; and $\mathrm{t}_{\mathrm{o}}$ is the age of the fish at zero length (Vakily \& Cham 2003). Rn is a goodness of fit index that select the best combination of $\mathrm{L} \infty$ and $\mathrm{K}$ in the length-frequency data set. The highest value of Rn indicates the best combination of $\mathrm{L} \infty$ and $\mathrm{K}$ (Abowei et al. 2009). A growth performance index, $\phi$ ' was calculated as $\phi^{\prime}=\log _{10} \mathrm{~K}+2 \log _{10} \mathrm{~L} \infty$ where the parameters $\mathrm{K}$ and $\mathrm{L} \infty$ are the parameters from the vBGF. A potential longevity, $\mathrm{t}_{\max }$ was calculated to estimate fish life-span with formula of $\mathrm{t}_{\text {max }}=3 / \mathrm{K}$.

Length-converted catch curve was used to convert length-frequency data into age-frequency data (Pauly et al. 1995). Total mortality (Z) was estimated from the lengthconverted catch curve with assumption that the collected length-frequency data represent a steady-state population (Vakily \& Cham 2003). Z was estimated by means of linear regression of the form $\ln \left(\mathrm{N}_{\mathrm{i}} / \Delta \mathrm{t}_{\mathrm{i}}\right)=\mathrm{a}+\mathrm{bt}_{\mathrm{i}}$ where $\mathrm{N}_{\mathrm{i}}$ is the number of fish in length class $I, \Delta \mathrm{t}_{\mathrm{i}}=\left(1 / \mathrm{K} \ln \left[\left(\mathrm{L} \infty-\mathrm{L}_{1}\right)\right.\right.$ $\left.\left./\left(\mathrm{L} \infty-\mathrm{L}_{2}\right)\right]\right)$ is time needed for the fish to grow through length class $I, \mathrm{t}_{\mathrm{i}}=(1 / \mathrm{K}) \ln \left[1-\left(\mathrm{L}_{\mathrm{t}} / \mathrm{L} \infty\right)\right]$ is relative age corresponding to the class mid-point of length class $I$ and $\mathrm{b}$ with sign changed gives $\mathrm{Z}$ without seasonality. Natural mortality (M) was estimated using Pauly's M equation;

$\log \mathrm{M}=-0.0066-0.279 \log \mathrm{L} \infty+0.6543 \log \mathrm{K}$ $+0.4634 \log \mathrm{T}$; where $\mathrm{T}$ is the mean annual surface water temperature in the river. The estimation of fishing mortality (F) was calculated by subtracting $\mathrm{M}$ from $\mathrm{Z}$. The exploitation rate (E) was computed using Gulland's expression (Gulland 1971) as $\mathrm{E}=\mathrm{F} / \mathrm{Z}$.

\section{RESULTS}

The water parameter varied very little among rivers as shown in Table 2. Dissolved oxygen content ranged from $7.71 \mathrm{mg} / \mathrm{L}$ in Sungai Kangar to $8.34 \mathrm{mg} / \mathrm{L}$ in Sungai Selama while for water $\mathrm{pH}$ fluctuated from 5.95 Sungai Kangar to 6.22 in Sungai Mahang. The water temperature varied from $23.6^{\circ} \mathrm{C}$ in Sungai Kangar to $21.82^{\circ} \mathrm{C}$ in Sungai Mahang. The highest conductivity was recorded in Sungai Selama $(19.6 \mu \mathrm{S} / \mathrm{cm})$ and lowest in Sungai Mahang $(16.51 \mu \mathrm{S} / \mathrm{cm})$. The TDS content ranged between $8-9.11 \mathrm{mg} / \mathrm{L}$. Water velocity ranged from 0.42 $\mathrm{m} / \mathrm{s}$ (Sungai Selama) to $0.69 \mathrm{~m} / \mathrm{s}$ (Sungai Mahang). Based on observation, Sungai Selama was wider and deeper compared to other rivers $(P<0.05)$. 
TABLE 2. The mean in situ reading (mean \pm s.e.) with their range (minimum-maximum) by sampling sites during the study period

\begin{tabular}{|c|c|c|c|}
\hline Sampling site & Sungai Mahang & Sungai Kangar & Sungai Selama \\
\hline $\mathrm{DO}(\mathrm{mg} / \mathrm{L})^{\mathrm{ns}}$ & $8.28 \pm 0.17$ & $7.71 \pm 0.14$ & $8.34 \pm 0.85$ \\
\hline Range (min-max) & $6.99-9.79$ & $6.75-8.43$ & $6.56-9.4$ \\
\hline $\mathrm{pH}^{\mathrm{ns}}$ & $6.22 \pm 0.71$ & $5.95 \pm 0.27$ & $6.05 \pm 0.51$ \\
\hline Range (min-max) & $4.79-7.45$ & $4.96-7.6$ & $5.06-8.4$ \\
\hline Conductivity $(\mu \mathrm{S} / \mathrm{cm})^{\mathrm{ns}}$ & $16.51 \pm 0.79$ & $18.6 \pm 0.17$ & $19.6 \pm 0.63$ \\
\hline Range (min-max) & $11-19.4$ & $17.2-19.4$ & $18-21.3$ \\
\hline Temperature $\left({ }^{\circ} \mathrm{C}\right)^{\mathrm{ns}}$ & $21.82 \pm 0.33$ & $23.6 \pm 0.57$ & $22.4 \pm 0.57$ \\
\hline Range (min-max) & $19.6-23.3$ & $20.6-25.7$ & $21-24.8$ \\
\hline $\mathrm{TDS}(\mathrm{mg} / \mathrm{L})^{\mathrm{ns}}$ & $8 \pm 0.58$ & $8.63 \pm 0.00$ & $9.11 \pm 0.58$ \\
\hline Range (min-max) & $7-9$ & $8-9$ & $8-10$ \\
\hline Velocity $(\mathrm{m} / \mathrm{s})^{\mathrm{ns}}$ & $0.69 \pm 0.14$ & $0.49 \pm 0.08$ & $0.42 \pm 0.08$ \\
\hline Range (min-max) & $0.44-0.86$ & $0.39-0.85$ & $0.36-0.57$ \\
\hline Depth $(\mathrm{cm})^{*}$ & $46.13 \pm 11.09$ & $17.5 \pm 7.33$ & $62 \pm 26.75$ \\
\hline Range (min-max) & $20-60$ & $10-35$ & $37-80$ \\
\hline Width $(\mathrm{m}) *$ & $4.91 \pm 1.10$ & $3.64 \pm 0.65$ & $8.87 \pm 0.75$ \\
\hline Range (min-max) & $4.14-6.14$ & $1.22-4.5$ & $6.5-12.2$ \\
\hline
\end{tabular}

Out of 126 stomachs examined, $121(96.03 \%)$ had food in them while the remaining five were empty $(3.97 \%)$. Formicidae was the most frequently occurring food category in all rivers, with $90 \%$ occurrence was in Sungai Mahang, 82.69\% (Selama) and 100\% (Kangar). Unidentified insects consisted of insects appendages formed the second most occurring food category, ranging from $55.56 \%$ (Kangar) to $66.67 \%$ (Mahang). The least occurring food categories were fish scales (1.67\%) and Isoptera (1.92\%) in Sungai Mahang and Sungai Selama, respectively.

The values of condition factor $(\mathrm{Kn})$ of $D$. regina implied that this fish enjoyed the same kinds of food items in all rivers $(p>0.05)$. Terrestrial Formicidae (ants) was the highest percentage of food composition in all rivers. Fish scales were present in Sungai Mahang while Isoptera was found only in Sungai Selama. The percentage of numerical ranged from $0.29 \%$ (Isoptera) to $64 \%$ (Formicidae) whereas for the percentage of points, the values varied from $0.16 \%$ (fish scales) to $74.03 \%$ (Formicidae) (Table 3).

Of the nine food categories, Formicidae was the most dominant food item in the stomach of $D$. regina especially in Sungai Kangar. Its dominance was above $50 \%$ based on the IRI hence the main diet for this species. The other food categories were only food supplements, as their importance ranged from $0.01 \%$ (Isoptera and fish scales) to $20.12 \%$ (unidentified insects). Ants are favourable diet for this species and its high abundance contributed to good growth performances of the fish with Kn values of above unity in all rivers (Table 3). Coleoptera was a relatively important diet of $D$. regina because its $\% \mathrm{~F}$ as well as IRI were fairly high in both Sungai Mahang and Sungai Selama.
Unfortunately, large components of other insects in the diet were beyond recognition due to incompleteness of their structures in the fish's stomach during the examination. A rather significant proportion of plant materials were eaten by $D$. regina which suggested the omnivorous feeding habit of this fish.

Living on the above diet, the fish growth performance showed that there was a significant relationship between the total length and weight of $D$. regina in Sungai Kerian Basin $(p<0.01)$ (Table 4$)$. The values of the slope $(b)$, categorized $D$. regina $(b=3.26)$ into heavy group or positively allometric growth. Estimated growth and mortality parameters of $D$. regina is summarized in Table 5. D. regina had a fast growth rate $\left(\mathrm{K}=1.20\right.$ year $\left.^{-1}\right)$ and short life-span $\left(\mathrm{t}_{\max }=3\right.$ years $)$ with its asymptotic length $(\mathrm{L} \infty)$ was $10.90 \mathrm{~cm}$ (Figure 2). Mortality estimation in the length-converted catch curve (Figure 3 ) indicated that this species suffered higher natural mortality than fishing mortality $(\mathrm{M}>\mathrm{F})$ because its exploitation rate was below the optimal exploitation of the stock $(E=0.13)$.

\section{DISCUSSION}

Except for Sungai Kangar which was slightly shallower and smaller than other rivers, all water parameters varied within small ranges suggesting the environmental condition for both fish and its preys were almost similar in all rivers. In this study, Formicidae was the main food items in the stomachs of D. regina and it was the most important diet in Sungai Mahang, Sungai Selama and Sungai Kangar. Other aquatic and terrestrial insects were also dominant in the stomachs of D. regina, indicating that this fish was mainly 


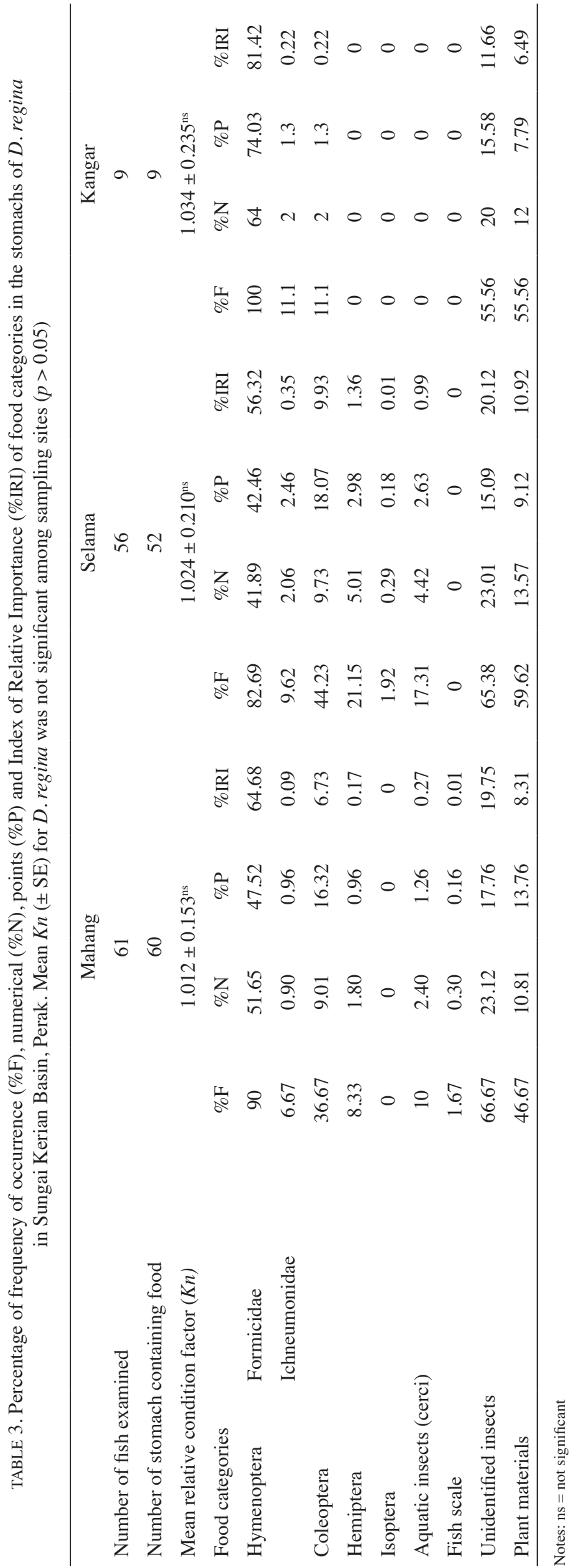



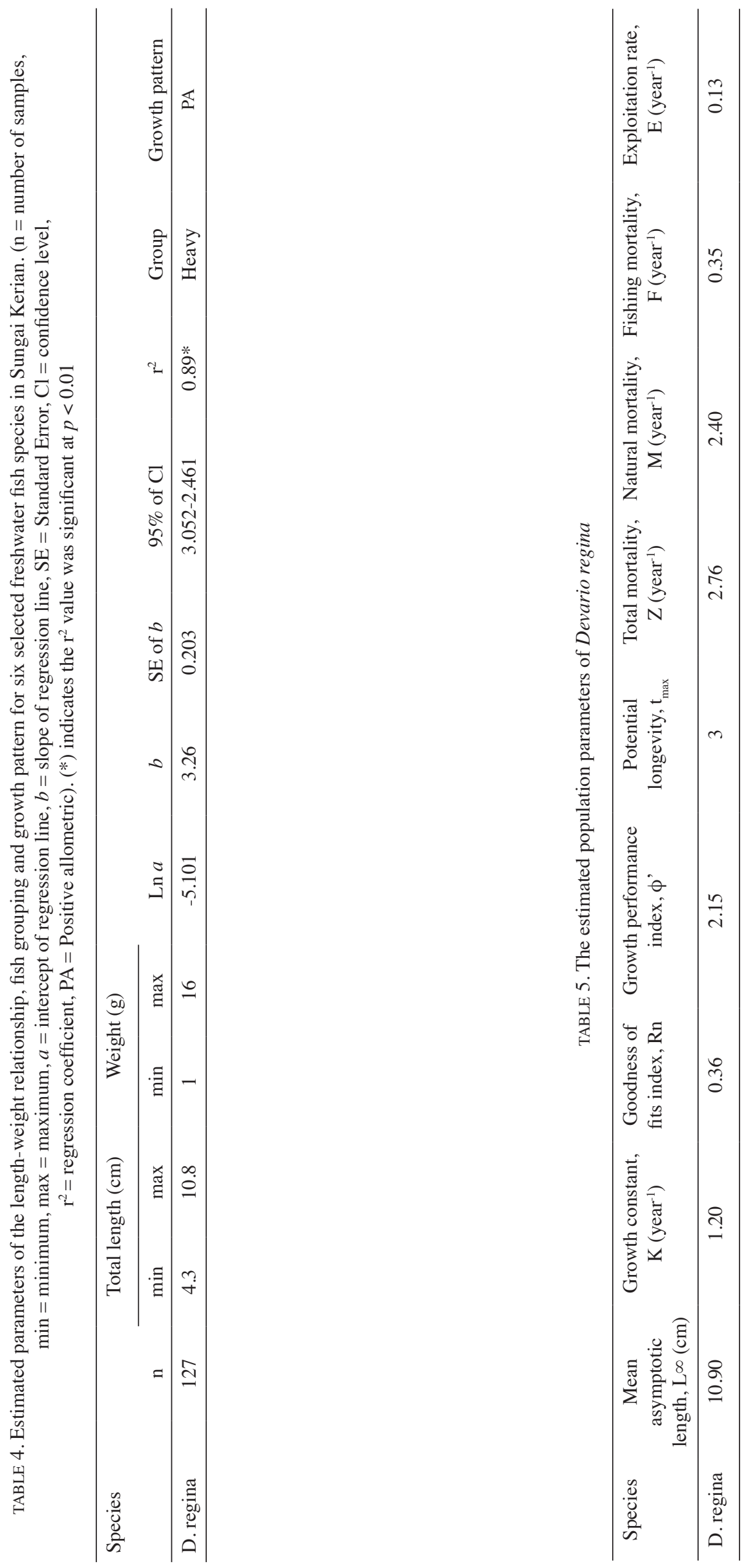


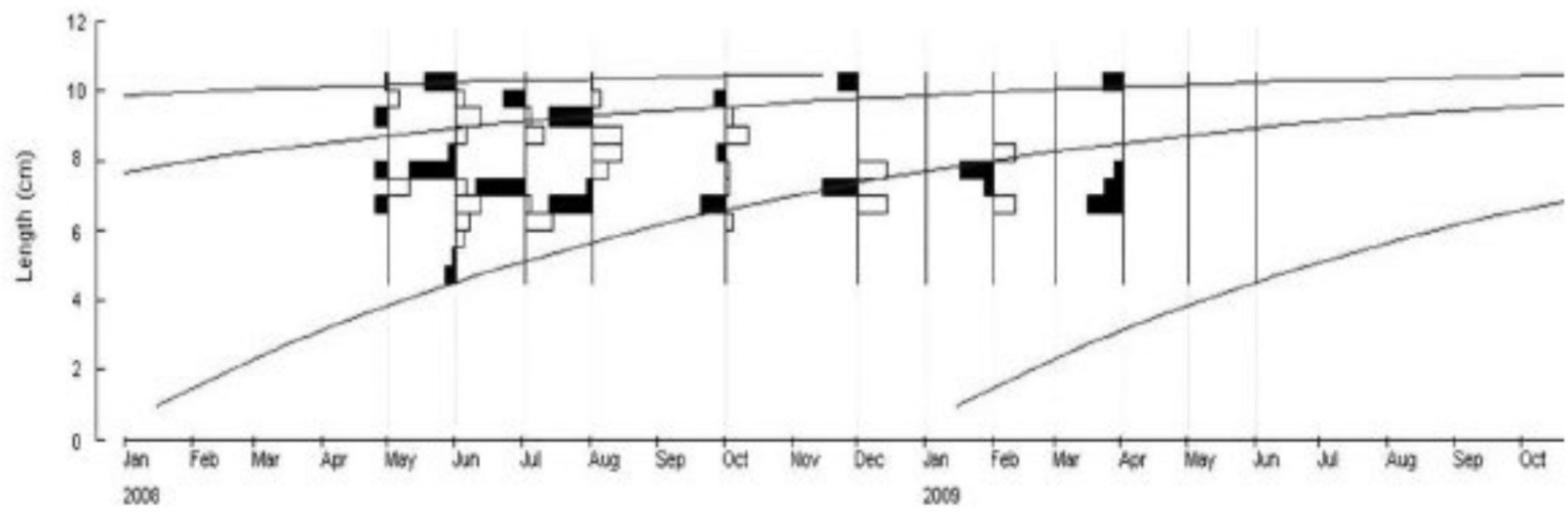

FIGURE 2. Growth curve using FiSAT II for D. regina in Sungai Kerian Basin, Perak. Lines superimposed on the restructured length-frequency histograms link successive peaks of growing cohorts as extrapolated by the model

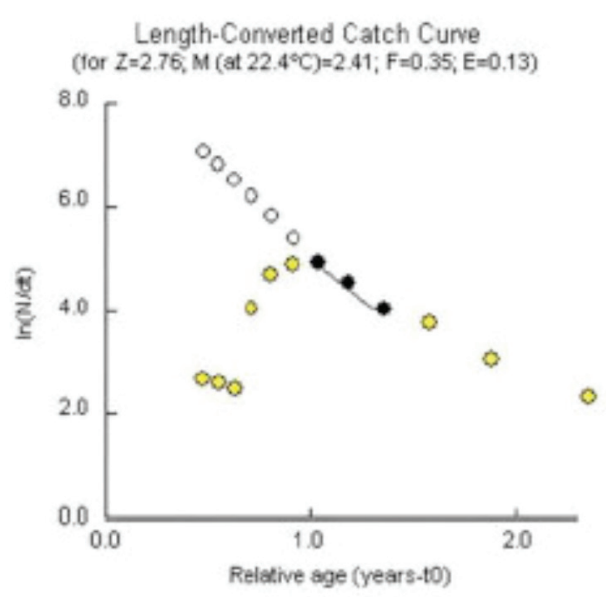

FIGURE 3. Length-converted catch curve. Dark circles represent the points used in calculating total mortality $(\mathrm{Z})$ through least squares regression lines

insectivorous. According to McClure et al. (2006), insects were the primary food sources for danion fishes while crustaceans, fish scales, algae and detritus are important supplements. In this study, most insect parts found in the stomach of D. regina belonged to ants, wasps from order Hymenoptera, beetles (Coleoptera), bugs (Hemiptera), termite (Isoptera) and small parts from aquatic insects probably larval stages of Ephemeroptera, Trichoptera or Plecoptera. Insect parts such as legs, wings and body that were partly digested were described as unidentified insects while seeds and leaf litter were included in plant materials. Although insectivorous, D. regina also ate on plant material which classified it as an omnivorous fish. This fish could also behave as an opportunistic feeder which consumes any available food. In either case, plant material was partly important in sustaining good growth performance of this species of fish in all rivers.

Formicidae (ants) made up over half of the stomach content, making this food item as the main diet while other insects (terrestrial and aquatic) and plant materials were supplement for this species. Ants are known as the most abundant food items and they contributed $60 \%$ of the total drift in the rivers (Bojsen 2005; Saul 1975). The importance of ants as the main food item has been documented for Knodus gamma and Prionobrama filigera when they consume large proportion of ants in forested areas (Bojsen 2005). Tilzey (1976) reported that beetles and ants contribute more than $63 \%$ of the diet of galaxiids (Family Galaxidae) in New South Wales. Usually plant materials are digested at a slower rate in the absence of cellulase or a method in breaking up the plant tissue (Blaber 1974). Thus, they are passed out in a partially undigested form.

Terrestrial and aquatic insects support a large biomass and provide high amount of nutrition to the fish (McDowall et al. 1996). Terrestrial insects such as beetles, ants, wasps and bugs that fall in the water become prey for stream fish (Mérona \& Rankin-de-Mérona 2004). Bojsen (2005) expected that riparian vegetation increases the abundance of terrestrial macroinvertebrates falling into the streams. Terrestrial insects that attract to fruits of riparian vegetation have a high tendency to fall into the stream contributing to the allocthonous inputs of organic matter (Parson 1991). There is a relationship between the composition of terrestrial macroinvertebrates and riparian canopy cover (Cloe \& Garman 1996, Kawaguchi \& Nakono 2001). Aquatic macroinvertebrates were found to be less important food source because they usually inhabit streambed sediments (Jacobsen et al. 2008) while D. regina is a surface feeder with upward directed mouth. Thus, this species feed mainly at the water surface. The presence of plant materials including seeds in the stomach of $D$. regina suggested that this species could be a significant seed dispersal agents for riparian vegetations along river banks such as rambutan (Nephelium lappaceum), durian (Durio zibethinus) and few flowering plants. Goulding (1980) also considered fish as a plant dispersal agent.

Based on the $\% \mathrm{~F}, \% \mathrm{~N}$ and $\% \mathrm{P}$ of the food items in the stomach of $D$. Regina, all rivers in Sungai Kerian basin provided similar food requirements for this species. The presence of riparian vegetations such as rambutan, durian, bamboo trees and few dipterocarps along Mahang, Kangar and Sungai Selama provided additional food sources for 
this species. The plants blocked parts of sunlight and prevents high growth of primary producers, thus most fish species in these rivers used food from allochthonous origin to maintain their food webs. A similar situation was observed in Amazonian streams where fish species depends very much on allocthtonous matter as food sources (LoweMcConnell 1987). In Thailand, D. regina is commonly found in a river with $70 \%$ canopy cover, fast flowing water and with sandy and hardy substrates (McClure et al. 2006). Water surface of fast flowing Sungai Mahang, Sungai Kangar and Sungai Selama were largely shaded and their substrates matched that of Thailand's river which explained the abundance of D. regina in these rivers. However, McClure et al. (2006) recorded the presence of insects, decapods, nematodes, gill arches and teeth from fishes, which are very different food sources from the food items identified in this study.

The allochthonous resources were important in small forest streams because there is a lack of autochthonous primary production (Horeau et al. 1996; Lowe-McConnell 1986; Saul 1975; Winemiller et al. 2008). The importance of terrestrial insects in fish diets had been shown in many fish species from tropical regions, such as in Amazonian rainforest (Knöppel 1970), Sri Lanka (Moyle \& Senanayake 1984) and in West Africa (Paugy \& Bénech 1989).

High values of regression coefficient $\left(\mathrm{r}^{2}\right)$ indicated the correlation between length and weight of $D$. regina was strong. Similarly, strong correlations of these two parameters were recorded by Ayoade and Ikulala (2007) and Jamabo et al. (2009), stating that an increase in weight is directly proportionate to an increase in length for a normal fish. The $b$ value (3.26) was in normal range for the growth of most fishes. Generally, most fishes scored $b$ values from 2 to 4 (Jamabo et al. 2009; Samat et al. 2008). D. regina experienced a positive allometric growth $(b>3)$ and heavy group, suggesting ample space area and food supply available for this species throughout the year.

Up to date, there was no recorded on the population parameters for D. regina in Malaysia. The analysis of its potential longevity indicated that $D$. regina grew very fast at a constant of 1.2 year $^{-1}$ with three year life-span following the fast growth trend of most tropical freshwater fishes (Afraei Bandpei et al. 2010; Sparre \& Venema 1998). The restructured vBGF growth curves indicated that major spawning time for D. regina was in January (Figure 2). The estimation of natural mortality $(\mathrm{M})$ was higher than the fishing mortality $(\mathrm{F})$ for this fish species suggesting that fishing activities influenced fish populations the least because this species is not a popularly harvested or eaten by human. Reduction in population numbers was probably due to predation, disease and death at the old ages (Abowei 2010; Sparre \& Venema 1998) since the fish was underexploited $(\mathrm{E}<0.5)$. Generally, the fish is optimally exploited when the rate of fishing mortality is equal to the rate of natural mortality $(\mathrm{F}=\mathrm{M}$ or $\mathrm{E}=0.5)$ (Gulland 1971; Hashemi et al. 2010).

\section{CONCLUSION}

In Sungai Kerian tributaries, D. regina was an omnivorous fish but mainly feeding on terrestrial ants accidentally falling from riparian trees onto the water surface. Other food materials were less commonly encountered from the fish stomach implying their low importance or low availability to the fish. The finding of this study clearly indicated the importance of riparian growth along rivers that served as insects' habitats especially for the ants. Enhancement and conservation of D. regina should include provision of these plants especially species preferred by ants and other insects in its diet such as fruit trees (rambutan \& durian) along the river banks. This first record of population parameter estimations for $D$. regina showed that the tributaries of Sungai Kerian provided good habitats supporting good growth of the fish. All parameter estimations can be used as a baseline for comparison with other population studies in tropical environments to bridge the information gap about tropical fishes.

\section{ACKNOWLEDGEMENTS}

We thank all individuals who are directly or indirectly involved in this research particularly those who help in the collection of fish and related data in the field. This research in funded by the Research University Grant 1001/ PBIOLOGI/815019 through Universiti Sains Malaysia.

\section{REFERENCES}

Abdurahiman, K.P., Harishnayak, T., Zacharia, P.U. \& Mohamed, K.S. 2004. Length-weight relationship of commercially important marine fishes and shellfishes of the southern coast of Karnataka, India. NAGA, ICLARM Q 27(1 and2): 9-14.

Abowei, J.F.N. 2010. Some population parameters of Distichodus rostratus (Gunther, 1864) from the fresh water reaches of Lower Nun River, Niger Delta, Nigeria. Advance Journal of Food Science and Technology 2(2): 84-90.

Abowei, J.F.N. 2009. The abundance, condition factor and lengthweight relationship of Cynoglossus senegalensis (Kaup,1958) from Nkoro River Niger Delta, Nigeria. Advance Journal of Food Science and Technology 1(1): 57-62.

Abowei, J.F.N., George, A.D.I. \& Deekae, S.N. 2009. The age and growth of Callinectes amicola (De Rochebrune, 1883) from Okpoda Creek, Niger Delta, Nigeria. Advance Journal of Food Science and Technology 1(2): 73-82.

Afraei Bandpei, M.A., Mashor, M.,Abdolmalaki, S., Keymaram, F., Isa, M.M. \& Janbaz, A.A. 2010. Age and growth of kutum (Rutilus frisii kutum, Kamensky, 1901) in Southern Caspian Sea. International Aquatic Research 2: 25-33.

Ambak, M.A., Isa, M.M., Zakaria, M.Z. \& Ghaffar, M.A. 2010. Fishes of Malaysia. Terengganu: Penerbit Universiti Malaysia Terengganu.

Assis, C.A. 1996. A generalised index for stomach contents analysis in fish. Scientia Marina 60(2-3): 385-389.

Ayoade, A.A. \& Ikulala, A.O.O. 2007. Length-weight relationship, condition factor and stomach contents of Hemichromis bimaculatus, Sarotherodon melanotheron and Chromidotilapia guentheri (Perciformes: Cichlidae) in Eleiyele Lake, Southwestern Nigeria. Revista de Biologia Tropical 55(3-4): 969-977. 
Blaber, S.J.M. 1974. Field studies of the diet of Rhabdosargus holubi (Pisces: Teleostei: Sparidae). Journal of Zoology 173(3): 407-417.

Bojsen, B.H. 2005. Diet and condition of three fish species (Characidae) of the Andean foothills in relation to deforestation. Environmental Biology of Fishes 73: 61-73.

Che Salmah, M.R., Abu Hassan, A. \& Ameilia, Z.S. 2001. Preliminary distribution of Ephemeroptera, Plecoptera and Trichoptera (EPT) in Kerian River Basin, Perak, Malaysia. Pertanika Journal of Tropical Agricultural Science 24(2): 101-107.

Che Salmah, M.R., Abu Hassan, A. \& Ameilia, Z.S. 2004. Odonate communities (Odonata: Insecta) in a tropical River Basin, Malaysia. Wetland Science 2(1): 1-9.

Cloe, W.W. \& Garman, G.C. 1996. The energetic importance of terrestrial arthropod input to three warm-water streams. Freshwater Biology 36: 105-114.

Efitre, J., Chapman, L.J. \& Murie, D.J. 2009. Fish condition in introduced tilapias of Ugandan crater lakes in relation to deforestation and fishing pressure. Environmental Biology of Fishes 85(1): 63-75.

Fang, F. \& Kullander, S.O. 2009. Devario xyrops, a new species of danionine fish from south-western Myanmar (Teleostei: Cyprinidae). Zootaxa 2164: 33-40.

Farzana, Y. \& Saira, K. 2008. Length-weight relationship and relative condition factor for the halfbeak Hemiramphus far Forsskål, 1775 from the Karachi coast. University Journal of Zoology Rajshahi University 27: 103-104.

Froese, R. 2006. Cube law, condition factor and weight-length relationship: History, meta-analysis and recommendations. Journal of Applied Ichthyology 22: 241-253.

Frota, L.O., Costa, P.A.S. \& Braga, A.C. 2004. Length-weight relationships of marine fishes from the central Brazilian coast. NAGA, ICLARM Q 27(1and2): 20-26.

Gayanilo, Jr., F.C., Sparre, P. \& Pauly, D. 2005. FISAT II. Food and Agriculture Organization of the United Nations.

George, A.D.I., Abowei, J.F.N. \& Inko-Tariah, M.B. 2009. The composition in different size groups and Index of Relative Importance (IRI) of Callinectes amnicola (De Rochebrune, 1883) food from Okpoda Creek, Niger Delta, Nigeria. International Journal of Animal and Veterinary Advances 1(2): 83-91.

Golam, M.M. \& Tawfeequa, R. 2006. Length-weight relationship, condition factor and sex-ratio of freshwater fish, Rhinomugil corsula (Hamilton) (Mugiliformes: Mugilidae) from Rajshahi, Bangladesh. Journal of Biological Sciences 14: 139-141.

González-Gándara, C., Pérez-Diaz, E., Santos-Rodríguez, L. \& Arias-González, J.E. 2003. Length-weight relationships of coral reef fishes from the Alacran Reef, Yucatan, Mexico. NAGA, ICLARM Q 26(1): 14-16.

Goulding, M. 1980. The Fishes and the Forest. Berkeley: University of California Press.

Gulland, J.A. 1971. The Fish Resources of the Ocean, West byFleet Survey. Fishing News (book) Limited, FAO.

Hanjavanit, C. \& Sangpradub, N. 2009. A preliminary examination of gut contents of three species of freshwater fishes, Barbonymus altus (Günther, 1868), Notopterus notopterus (Pallas, 1769) and Ompok bimaculatus (Bloch, 1794) from Nong Han Kumphawapi, Udon Thani, Thailand. Khon Kaen University Science Journal 37: 1-10.

Hashemi, S., Mohammadi, G. \& Eskandary, G. 2010. Population dynamics and stock assessment of Hilsa Shad, (Tenalosa ilisha Hamilton-Buchanan, 1822) in Coastal Waters of Iran (Northwest of Persian Gulf). Australian Journal of Basic and Applied Sciences 4(12): 5780-5786.

Horeau, V., Cerdan, P., Champeau, A. \& Richard, S. 1998. Importance of aquatic invertebrates in the diet of rapidsdwelling fish in the Sinnamary River, French Guiana. Journal of Tropical Ecology 14: 851-864.

Hynes, H.B.N. 1950. The food of freshwater sticklebacks (Gasterosteus aculeatus and Pygosteus pungitius) with a review of methods used in studies of the food of fishes. Journal of Animal Ecology 19: 36-58.

Hyslop, E.J. 1980. Stomach content analysis - A review of methods and their application. Journal of Fish Biology 17: 411-429.

Jacobsen, D., Cressa, C., Mathooko, J.M. \& Dudgeon, D. 2008. Macroinvertebrates: Composition, life histories and production. In Tropical Stream Ecology, edited by Dudgeon, D. Oxford: Academic Press. pp. 65-105.

Jamabo, N.A., Chindah, A.C. \& Alfred-Ockiya, J.F. 2009. Length-weight relationship of a Mangrove Prosobranch Tympanotonus fuscatus var fuscatus (Linnaeus, 1758) from the Bonny Estuary, Niger Delta, Nigeria. World Journal of Agricultural Sciences 5(4): 384-388.

Kawaguchi, Y. \& Nakano, S. 2001. Contribution of terrestrial invertebrates to the annual resource budget for salmonids in forest and grassland reaches of a headwater stream. Freshwater Biology 46: 303-316.

Kleiber, P. \& Pauly, D. 1991. Graphical representations of ELEFAN 1 response surfaces. Fishbyte 9(2): 45-49.

Knöppel, H.A. 1970. Food of central Amazonian fishes: Contribution to the nutrient-ecology of Amazonian rain-forest streams. Amazoniana 2: 257-352.

Kolaneci, V., Shegani, Ç., Nikolla, M. \& Kuka, B. 2010. Some biological properties of two cyprinid fishes living in Shkodra Lake. Proc. BALWOIS, Ohrid, Macedonia. pp. 1-6.

Kottelat, M., Whitten, A.J., Kartikasari, S.N.\& Wirjoatmodjo, S. 1993. Freshwater Fishes of Western Indonesia and Sulawesi. Hong Kong: Periplus Editions Limited.

Laghari, M.Y., Narejo, N.T., Mahesar, H., Lashari, P.K. \& Abid, M. 2009. Length-weight relationship and condition of indigenous catfish, Rita rita (Hamilton) from cemented ponds University of Sindh, Jamshoro. Sindh University of Research Journal (Sci Ser.) 41(2): 47-52.

Le Cren, E.D. 1951. The length-weight relationship and seasonal cycle in the gonad weight and condition in the perch (Perca fluviatilis). Journal of Animal Ecology 20: 201-219.

Lima-Junior, S.E. \& Goitein, R. 2001. A new method for the analysis of fish stomach contents. Maringá 23(2): 421-424.

Lowe-McConnell, R.H. 1986. Fish of the Amazon system. In The Ecology of River System, edited by Davies, D.R. \& Walker, K.F. Netherlands: Springer. pp. 339-352.

McClure, M.M., McIntyre, P.B. \& McCune, A.R. 2006. Notes on the natural diet and habitat of eight danionin fishes, including the zebrafish Danio rerio. Journal of Fish Biology 69: 553-570.

McDowall, R.M., Main, M.R., West, D.W. \& Lyon, G.L. 1996. Terrestrial and benthic foods in the diet of the shortjawed kokopu, Galaxias postvectis Clarke (Teleostei: Galaxiidae). New Zealand Journal of Marine and Freshwater Research 30: 257-269.

Merritt, R.W., Cummins, K.W. \& Berg, M.B. 2008. An Introduction of Aquatic Insects of North America. 4th ed. Dubuque: Kendall/Hunt Publishing Company. 
Merritt, R.W. \& Cummins, K.W. 1996. An Introduction of Aquatic Insects of North America. 3rd ed. Dubuque: Kendall/Hunt Publishing Company.

Mérona, B. \& Rankin-de-Mérona, J. 2004. Food resource partitioning in a fish community of the central Amazon floodplain. Neotropical Ichthyology 2(2): 75-84.

Mohsin, A.K.M. \& Ambak, M.A. 1983. Freshwater Fishes of Peninsular Malaysia. Serdang: Universiti Pertanian Malaysia.

Moyle, P.B. \& Senanayake, F.R. 1984. Resource partitioning among the fishes of rainforest streams in Sri Lanka. Journal of Zoology 202: 195-223.

Odat, N. 2003. Length-weight relationship of fishes from coral reefs along the coastline of Jordan (Gulf of Aqaba). NAGA, ICLARM Q 26(1): 9-10.

Offem, B.O., Samsons, Y.A. \& Omoniyi, I.T. 2009. Lengthweight relationship, condition factor and sex ratio of forty six important fishes in a Tropical Flood River. Journal of Fisheries and Hydrobiology 4(2): 65-72.

Parson, A. 1991. The Conservation and Ecology of Riparian Tree Communities in the Murray Darling Basin, New South Wales: Literature Review. Sydney: NSW National Parks and Wildlife Service.

Paugy, D. \& Bénech, V. 1989. Poissons d'eau douce des bassins còtiers du Togo (Afrique de I'Ouest). Revue d'Hydrobiolgie Tropicale 22: 295-316.

Pauly, D. 1983. Some simple methods for the assessment of tropical fish stock. FAO Technical Paper 234: 52.

Pauly, D., Moreau, J. \& Abad, N. 1995. Comparison of agestructured and length-converted catch curves of brown trout, Samo truta in two French Rivers. Fisheries Research 22: 197-204.

Rainboth, W.J. 1996. Fishes of the Cambodia Mekong. Rome: Food and Agriculture Organization of the United Nation.

Sachidanandamurthy, K.L. \& Yajurvedi, H.N. 2008. A study on growth co-efficient and relative condition factor of the major carp (Catla catla) in two lakes differing in water quality. Applied Ecology and Environmental Research 6(3): 33-47.

Samat, A., Shukor, M.N., Mazlan, A.G., Arshad, A. \& Fatimah, M.Y. 2008. Length-weight relationship and condition factor of Pterygoplichthys pardalis (Pisces: Loricariidae) in Malaysia Peninsula. Research Journal of Fisheries and Hydrobiology 3(2): 48-53.

Saul, W.G. 1975. An ecological study of fishes at a site in upper Amazonian Ecuador. Proceedings of the Academy of Natural Science of Philadelphia 127(12): 93-134.

Schneider, J.C., Laarman, P.W. \& Gowing, H. 2000. Chapter 17: Length-weight relationship. Manual of Fisheries Survey Method 2: 1-16.

Shah, A.S.R.M., Zarul Hazrin, H. \& Shahrul Anuar, M.S. 2009. Freshwater fishes of Gunung Jerai, Kedah Darul Aman: A preliminary study. Tropical Life Sciences Research 20(2): 59-70.

Smith, K.M.M. 1996. Length/weight relationship of fishes in a diverse tropical freshwater community, Sabah, Malaysia. Journal of Fish Biology 49: 731-734.

Sparre, P. \& Venema, S.C. 1998. Introduction to tropical fish stock assessment. FAO Fisheries Technical Paper 1:306-337.

Swynnerton, G.H. \& Worthington, E.B. 1940. Notes on the food of fish in Haweswater (Westmorland). Journal of Animal Ecology 9: 183-187.
Thomas, J., Venu, S. \& Kurup, B.M. 2003. Length-weight relationship of some deep-sea fish inhabiting the continental slope beyond $250 \mathrm{~m}$ depth along the West Coast of India. NAGA, ICLARM Q 26(2): 17-20.

Tilzey, R.D.J. 1976. Observations on interactions between indigenous Galaxiidae and introduced Salmonidae in the Lake Eucumbene catchment, New South Wales. Australian Journal of Marine and Freshwater Research 27: 551-564.

Uneke, B.I., Nwani, C.D., Okogwu, O.\& Okoh, F. 2010. Growth, mortality, recruitment and yield of Pellonula leonensis Boulenger, 1917 (Osteichthyes: Clupeidae) in a tropical flood river system. Journal of Fisheries International 5(1): 19-26.

Vakily, J.M. \& Cham, A. 2003. Growth, feeding and reproduction of the West African Ilisha, Ilisha africana off Sierra Leone. In Fish Biodiversity: Local Studies as Basis for Global Inferences, edited by Palomares, M.L.D., Samb, B., Diouf, T., Vakily, J.M. \& Pauly, D. ACP-EU Fisheries Research Report. pp. 46-57.

Winemiller, K.O., Agostinho, A.A. \& Caramaschi, E.P. 2008. Chapter 15: Fish ecology in tropical streams. In Tropical Stream Ecology, edited by Dudgeon, D. San Diego: Elsevier/ Academic Press. pp. 107-146.

Yamagishi, Y., Mitamura, H., Arai, N., Mitsunaga, Y., Kawabata, Y., Khachapicha, M. \& Viputhanumas, T. 2005. Feeding habits of hatchery-reared young Mekong giant catfish in a fish pond and in Mae Peum reservoir. Proceedings of the 2nd International Symposium on SEASTAR 2000 and Asian Bio-logging Science (The 6th SEASTAR 2000 Workshop). pp. 17-22.

Yap, S. 1990. A Malaysian tidal barrage incorporating a fishery component: Perspectives. Reservoir fisheries of Asia. Proceedings of the 2nd Asian Reservoir Fisheries Workshop held in Hangzhou, People's Republic of China, 15-19 October. pp. 76-103.

Yap, S. 1988. Food resource utilization partitioning of fifteen fish species at Bukit Merah Reservoir, Malaysia. Hydrobiologia 157: 143-160.

Yule, C.M. \& Yong, H.S. 2004. Freshwater Invertebrates of the Malaysian Region. Kuala Lumpur: Academy of Science Malaysia.

Zakaria-Ismail, M. \& Lim, K.K.P. 1995. The fish fauna of Tasik Temengor and its Tributaries South of Banding, Hulu Perak, Malaysia. Malaysia Nature Journal 48: 319-332.

School of Biological Sciences

Universiti Sains Malaysia

11800 Penang, Pulau Pinang

Malaysia

*Corresponding author; email: shafiqzakeyuddin@gmail.com

Received: 26 January 2016

Accepted: 30 December 2016 